\title{
THE GORE SUB-STATION OF THE GRASSLANDS DIVISION
}

\author{
By J. P. LAMBERT, Agrostologist, Grasslands \\ Division, Gore.
}

Until 1938 the Grasslands Division carried out all its critical studies at Palmerston North. A substation was then established on the Crop Research area at Lincoln, in Canterbury. In 1945 the Gore substation was established. A most important reason for the establishment of sub-stations is to be able to continue studies in different climates and to investigate any problems specific to a particular region. Climate is a reflex of many interacting factors such as temperature, rainfall,. length of day, wind, etc.

Earth temperatures serve as an indication of the differences which exist between Palmerston North, Lincoln, and Gore. The average temperature for July at 4in. depth at Palmerston North is about $44^{\circ} \mathrm{F}$., for Lincoln about $38^{\circ} \mathrm{F}$, and for East Gore about $35^{\circ} \mathrm{F}$. The critical temperature for the nitrogen-fixing organisms of the soil is in the vicinity of $38^{\circ} \mathrm{F}$., and there may be three months of the year at Gore when nitrogen fixation is at a standstill, while this process may continue through the year at Palmerston North. Thus, indirectly, temperature has an effect on pasture growth apart from its direct effect. The lower temperatures of Southland are reflected in the emphasis placed on the provision of winter fodder crops in Southland.

In the first stages of the establishment of the Gore sub-station, the study of known strains of pasture species, progeny testing of breeding material, and the repetition of ecological trials begun at Palmerston North has been a major activity. This phase must be regarded as having certain minimum requirements, and when those requirements have been satisfied other more local problems can be investigated.

$A_{\Perp}$ brief account of work in progress at Gore follows :-

Plant breeding is not carried out, but progeny testing has been possible. By this means parent material can be evaluated more readily. Tn 
general, the best progenies at Palmerston North are the best at Gore, as has been the case at Lincoln. Following are the percentages of various strains and species of ryegrass surviving in April, 1950, 18 months from planting as spaced plants.

Perennial ryegrass: "False," 18 ; South Island Old Pasture 61; Pedigree, 98.

Italian ryegrass: Certified (non-pedigree), 16 ; Pedigree 90.

Short-rotation ryegrass: Original H1, 84; 1946 strain, 96; 1948 strain, 99.

The improvement in persistency is notable, and the results follow closely similar testing at Palmerston North. The same type of work is being undertaken with cocksfoot, timothy, and red and white clovers. In all cases the superiority of bred material is shown in the spaced plant trials.

\section{RYEGRASS PRODUCTION}

A grazing trial of perennial ryegrass strains in which the strains were sown in $1 / 10$ acre paddocks was sown on September 23, 1947. The ryegrass strains were sown at $401 \mathrm{~b}$. per acre, and pedigree white clover at $31 \mathrm{~b}$. per acre was sown throughout. Strains of ryegrass included three strains of the Welsh Plant Station, Aberystwyth. These are S.23, an extreme pasture type, 5.24, a hay type, and S.101, a dual purpose type. The production to May 15, 1950 , is shown in the table.

Table 1

Production in lb. dry matter per acre from perennial ryegrass strains, from sowing (September 23, 1947) to May 15, 1950.

Botanical Composition

\begin{tabular}{lcccc}
\cline { 2 - 4 } \multicolumn{1}{c}{ Strain } & Ryegrass & $\begin{array}{c}\text { White } \\
\text { Clover }\end{array}$ & $\begin{array}{c}\text { Other } \\
\text { Species }\end{array}$ & Total \\
\hline k.23 & 20850 & 6193 & 2555 & 29598 \\
S.24 & 22473 & 7533 & 3516 & 33522 \\
S.101 & 19751 & 8528 & 3267 & 31546 \\
N.Z. Pedigree & 26316 & 5961 & 2659 & 34936 \\
Sth. Is. Old Pasture & 18303 & 8243 & 4111 & 30657
\end{tabular}

As some strains of ryegrass weaken, white clover becomes more prominent, so that the total productions do not vary as widely as the ryegrasses themselves. Seasonal production is affected, however, as it is the ryegrass which makes greatest growth in the late autumn to early spring. 
To obtain yields from Italian, short-rotation and perennial ryegrasses a replicated plot trial was sown in November, 1948. Red and white clovers were sown with the ryegrasses. Delay in initial grazing caused considerable clover suppression, which is reflected in the lower yields as compared with the trial described previously. Oversowing with the clovers has produced a good clover element and this should improve production in the coming season. In the table are set out yields from this trial.

Table 2

Production in lb. dry matter per acre of ryegrass only from sowing (November 9, 1948) to May 16, 1950.

Species or Strain

\begin{tabular}{|c|c|c|c|c|c|}
\hline & $\begin{array}{l}\text { Pedigre } \\
\text { Italian }\end{array}$ & $\begin{array}{l}\text { Certified } \\
\text { Non-pedi- } \\
\text { gree ftalian }\end{array}$ & $\begin{array}{c}\text { Short- } \\
\text { Rotation }\end{array}$ & $\begin{array}{l}\text { Pedigree } \\
\text { Perennial }\end{array}$ & $\begin{array}{l}\text { "False" } \\
\text { Peren- } \\
\text { nial }\end{array}$ \\
\hline $\begin{array}{l}\text { Spring } \\
\text { Summer } \\
\text { Autumn } \\
\text { Winter } \\
\text { Spring } \\
\text { Summer }\end{array}$ & $\begin{array}{r}353 \\
\mathbf{3 7 0 4} \\
1392 \\
1001 \\
2370 \\
1038 \\
\mathbf{4 5 4}\end{array}$ & $\begin{array}{r}216 \\
3227 \\
1183 \\
577 \\
1506 \\
944 \\
364\end{array}$ & $\begin{array}{r}342 \\
3967 \\
1689 \\
1086 \\
2459 \\
1163 \\
605\end{array}$ & $\begin{array}{r}161 \\
2520 \\
1137 \\
608 \\
2693 \\
1135 \\
528\end{array}$ & $\begin{array}{r}226 \\
3161 \\
1189 \\
422 \\
1467 \\
405 \\
169\end{array}$ \\
\hline OTAL & 10312 & 8017 & & 8782 & 7039 \\
\hline
\end{tabular}

The winter production of Italian and short-rotation ryegrasses compared with that of perennial ryegrass is well illustrated. The declines in yield generally as the trial progressed are general, and this was assisted by drying out last summer, which was more pronounced in the absence of good clover growth.

\section{COCKSFOOT}

A paddock trial was sown in November, 1946, to compare various strains of cocksfoot. The table shows the average production per year of the trial.

Table 3 acre.

Average annual production in lb. dry matter per

\begin{tabular}{|c|c|c|c|c|}
\hline \multirow{2}{*}{$\begin{array}{l}\text { Strain } \\
\text { C.23 } \\
\text { Nucleus } \\
\text { Southland }\end{array}$} & \multicolumn{3}{|c|}{ Cocksfoot White Clover Other Species } & Total \\
\hline & $\begin{array}{l}\mathbf{2 3 4 8} \\
3124 \\
2431\end{array}$ & $\begin{array}{l}\mathbf{1 2 4 5} \\
1115 \\
\mathbf{1 1 8 2}\end{array}$ & $\begin{array}{l}4380 \\
4305 \\
4651\end{array}$ & $\begin{array}{l}7973 \\
8544 \\
8264\end{array}$ \\
\hline
\end{tabular}


"Other Species" consisted> for the first two years largely of a "false" perennial ryegrass sown to enable early grazing, and which persisted longer than expected. The C.23 strain is the pedigree cocksfoot on the market. The "Nucleus" strain is a new one produced at Grasslands, Palmer\&on North, and now in the late stages of multiplication before being released, and the "Southland" strain is of the certified Akaroa type.

The nucleus stock seed of the new strain has been harvested at Gore over the past two seasons from an area sown in 24in. drills and has yielded 498 and $4801 \mathrm{~b}$. machine-dressed seed per acre in 1949 and 1950. These yields have been obtained with the use of $2 \mathrm{cwt}$. of superphosphate and 4cwt. sulphate of ammonia per acre per year.

A trial to compare the new strain with C.23 and Akaroa for seed production has had two harvests. The average per acre production for the two years is shown in the table.

\section{Table 4}

Average seed production per acre for the years 1949 and 1950 of three cocksfoot strains.

\begin{tabular}{lcc}
\hline Strain & M/D Seed & Pure \\
\cline { 2 - 3 } & lb. & Germination Seed \\
Nucleus & 600 & 462 \\
C.23 & 638 & 446 \\
Akaroa & 674 & 498 \\
\hline
\end{tabular}

Further trials with different rates of application of sulphate of ammonia and intensities of grazing are being planned.

\section{TIMOTHY}

A replicated trial was sown in November, 1948, to compare the herbage productions of American, Southland, Certified (S.48 N.Z. grown), and a new strain developed at Palmerston North largely from S.48. A table is presented to show the production from the strains. 


\section{Table 5}

Production in lb. dry matter per acre from timothy strains from a trial sown on November 9, 1948, to May 16, 1950, together with associated species.

\begin{tabular}{lcccr}
\hline & American & Southland & S.48 & Nucleus \\
\hline Timothy & 5530 & 5100 & 8011 & 8725 \\
Other Species & 4589 & 4693 & 3190 & 3007 \\
\cline { 2 - 3 } & 10119 & 9793 & $\overline{11201}$ & 11732
\end{tabular}

The difference in production of the pedigree strains compared with the others (S.48 and "Nucleus") is made up to a large degree by "Other Species," which are mainly red and white clovers. The pedigree strains, however, have a much longer growing season than the American or Southland. Two of the strains are compared for production in late autumn to early spring in the following table.

Table 6

Production in lb. dry matter per acre of two strains of timothy compared at "out-of-season" dates.

\begin{tabular}{llcc}
\hline \multirow{2}{*}{ Strain } & Dry Matter & $15 / 2 / 49$ to & $4 / 4 / 49$ \\
\hline Nucleus Pedigree & Total- & 1390 & $5 / 7 / 49$ \\
\cline { 2 - 3 } Southland & Timothy & 1255 & 504 \\
& Total & 720 & 111 \\
& Timothy & 368 & 77 \\
\hline
\end{tabular}

It is evident from these vields that the pedigree type of timothy is capable of making an appreciable contribution to the winter ration of the grazing animal.

\section{GRAZING MANAGEMENT}

A complex mixture consisting of perennial ryegrass 20lb., short-rotation ryegrass $201 \mathrm{lb}$., cocksfoot $5 \mathrm{lb}$, timothy 3lb., red clover 6lb. white clover 3lb., per acre was sown on October 14, 1948. This was grazed as on a rotational system until the end of March, 1949, when the area was fenced into four paddocks and several grazing managements were begun. 
These were (1) Rotational, the pasture growing 9in. to 10in. high between grazings. (2) Rotational, the pasture growing $3 \mathrm{in}$. to $4 \mathrm{in}$. high between grazings. (3) Set stocking with close winter grazing and lenient spring to autumn grazing. (4) Set stocking, the pasture kept close grazed at all times.

The seasonal and total growth under these management's is shown in the table.

\section{Table 7}

Seasonal and total growth from several grazing managements from March 23, 1949, to March 23, 1950 in lb. dry matter per acre, to nearest $100 \mathrm{lb}$

\begin{tabular}{|c|c|c|c|c|c|}
\hline- & & $(1)$ & (2) & (3) & $--\overline{(4)}$ \\
\hline Season & & $\begin{array}{l}\text { Rotational } \\
\text { 9in. to 10in. }\end{array}$ & $\begin{array}{l}\text { Rotational } \\
\text { 3in. to 4in. }\end{array}$ & $\begin{array}{c}\text { Set Close } \\
\text { Winter } \\
\text { Lenient } \\
\text { Summer }\end{array}$ & $\begin{array}{c}\text { Set } \\
\text { Stocking }\end{array}$ \\
\hline Winter & 1949 & 1500 & 1500 & 800 & 700 \\
\hline Spring & 1949 & 3900 & 3500 & 3100 & 2500 \\
\hline Summer & 1949-50 & 4700 & 4400 & 5000 & 4000 \\
\hline Autumn & 1950 & 1600 & 2200 & 1200 & 1100 \\
\hline TOTAL & & 11700 & 11600 & 10100 & 8300 \\
\hline
\end{tabular}

The high winter production from the two rotational systems is evident, and spring production is again higher. The change in management on system (3) is immediately reflected. The high summer production of this latter system is due to a high clover content following close winter grazing and lenient summer grazing. On calculating the average number of sheep carried, from the grazing records, it was found that system (1) averaged 9.4 sheep per acre, (2) 9.0 sheep, (3) 7.7 sheep, (4) 6.9 sheep per acre over the year. Winter spelling on system (1) resulted in serious suppression of the clover's, but these have been increased by careful management. It has been decided to alternate the paddock previously under system (3) with (1) for future winter spelling.

The relative numbers of perennial and short-rotation ryegrass plants persisting in June, 1950, were 'estimated, with the results as shown in the table. 
Table 8

Perennial and short-rotation ryegrass plants as percentages of total ryegrass plants in June, 1950, after 15 months of differential treatment.

\begin{tabular}{crc}
\hline Treatment & $\begin{array}{c}\text { Short-rotation } \\
\text { ryegrass }\end{array}$ & $\begin{array}{c}\text { Perennial } \\
\text { ryegrass }\end{array}$ \\
\hline 1. & 51 & 49 \\
2. & 42 & 58 \\
3. & 40 & 60 \\
4. & 17 & 83
\end{tabular}

The short-rotation ryegrass plants identified in (4) were perennial-like in habit, and were planted in boxes in the glasshouse and allowed to grow before final identification. It is interesting to note that the three months of close grazing under set stocking imposed on (3) in the first winter has not markedly reduced the proportion of short-rotation ryegrass. Also in (4) the proportion of short-rotation ryegrass is higher than expected. The plants surviving were not able to produce, and in this respect it was noted that in (4) there were abundant plants of timothy, cocksfoot, and red clover, which also could do little other than survive in an unproductive form.

\section{THE EFFECT OF CLOVERS ON ASSOCIATED GRASSES}

The chemical side of this subject was described in detail by Dr. Melville at the 1949 Conference, when dealing with a Palmerston North trial, and it is intended here merely to indicate the effect of clover shown in total yield from swards and in the yield of associated grasses at Gore. The table shows the yields from a grass mixture with and without red and white clover, with and without lime and superphosphate, and with and without return of dung and urine.

Table 9

The effect of clovers, lime and superphosphate, and dung and urine on a grass mixture. Yields in $\mathrm{lb}$. dry matter per acre for the year ended May 31, 1950.

\begin{tabular}{|c|c|c|c|c|c|c|}
\hline & $\begin{array}{l}\text { No retur } \\
\text { Grass no } \\
\text { Clover: }\end{array}$ & $\begin{array}{l}\text { of dung } \\
\text { Crass + } \\
\text { Clovers }\end{array}$ & $\begin{array}{c}\& \text { urine. } \\
\% \\
\text { Clover }\end{array}$ & $\begin{array}{l}\text { Full retur } \\
\text { Grass no } \\
\text { Clovers }\end{array}$ & $\begin{array}{l}\text { of dung } \\
\text { Grass }+ \\
\text { Clovers }\end{array}$ & $\begin{array}{c}\text { urine. } \\
\text { of } \\
\text { Clovel }\end{array}$ \\
\hline $\begin{array}{l}\text { No lime or } \\
\text { superphosphate } \\
\text { Lime and }\end{array}$ & 563 & 3032 & 75 & 2441 & 5290 & 44 \\
\hline superphosphate & 520 & G131 & 76 & 3374 & 8193 & 42 \\
\hline
\end{tabular}


Where grass alone is sown and no dung or urine is returned, the addition of lime and phosphate has had no effect. Where dung and urine are returned to grass alone a response has been obtained, but this is diminishing as the trial proceeds. The inclusion of clovers has resulted in a big increase in total yield, which is more marked where lime and phosphate have been added. The increase in the associated grass where clovers are added is also considerable. Where the dung and urine are returned the increase in total yield and vield of grass from the grass-clover plots is most marked.

\section{WINTER GREENFEED TRIALS}

Over the past two winters yields have been measured from Italian ryegrass, Western Wolths ryegrass, ryecorn, and mixtures of Newal barley with Italian and Western Wolths ryegrasses. Data from the 1950 trial are presented in the table.

\section{Table 10}

Yields in lb. dry matter per acre from winter greenfeeds sown on March 3, 1950.

\begin{tabular}{|c|c|c|c|c|c|c|c|c|c|}
\hline $\begin{array}{l}\text { Date of } \\
\text { Grazing } R\end{array}$ & $\begin{array}{l}\text { Italia } \\
\text { yegras }\end{array}$ & $\begin{array}{c}\text { Western } \\
\text { w o l t h } \mathrm{s}\end{array}$ & $\begin{array}{l}\text { N.I.A.B. } \\
\text { Ryecoln }\end{array}$ & $\begin{array}{l}\text { Newal } \\
\text { Italiar } \\
\text { Cereal }\end{array}$ & $\begin{array}{l}\text { Barley } \\
\text { Ryeg } \\
\text { Grass }\end{array}$ & $\begin{array}{c}\text { plus } \\
\text { Trass } \\
\text { Total }\end{array}$ & $\begin{array}{r}\text { Newa } \\
\text { Wes } \\
\text { Cereal }\end{array}$ & $\begin{array}{l}\text { Barley } \\
\text { ern W } \\
\text { Grass }\end{array}$ & $\begin{array}{l}\text { ey plus } \\
\text { Wolths } \\
\text { s Total }\end{array}$ \\
\hline April 21 & 489 & 619 & 866 & 483 & 43 & 532 & 304 & 66 & 370 \\
\hline May 25 & 372 & 414 & 420 & 564 & 127 & 691 & 443 & 164 & 607 \\
\hline July 21 & 417 & 669 & 352 & 186 & 220 & 406 & 146 & 295 & 441 \\
\hline August 21 & 359 & 532 & 394 & 71 & 298 & 363 & 56 & 287 & 343 \\
\hline $\begin{array}{l}\text { Total to } \\
\text { date }\end{array}$ & 1637 & 2234 & 20022 & 1310 & 688 & 1998 & 949 & 812 & ${ }_{-}^{1761}$ \\
\hline
\end{tabular}

The object of mixing Newal barley with the grasses was to try to spread production, the barley producing in the early part and the grass in the latter part of the neriod. The mixture has been better in both years than Italian ryegrass alone, but Western Wolths and ryecorn have been superior at the first grazing in both years. In 1949 the trial was sown a month later than in 1950. and yields were lower. In both years Western Wolths and ryecorn have produced similarly, but in 1950 the former has outyielded the ryecorn in the late winter.

\section{FARMING SYSTEMS}

To investigate how various methods of animal fodder provision are able to provide the theoretical nutrient requirements of a dairy cow through the 
year, several farmlets are in operation. The systems are based on pasture with the variations of: (1) No supplementary crops, hay, or silage, and surplus growth consumed by animals bought in. (2) Surplus summer growth made into hay and fed back; no crops. (3) Special-purpose pastures to replace hay or crops. (4) Swedes and kales for winter and early spring feeding. (5) As for (4), but the pasture species are of non-pedigree origin. In (1)-(4) the pasture species are of pedigree origin.

The efficiency of these systems will take at least five years to ascertain, and by then any effects on soil fertility and production should be measurable. It is not proposed to present data at this early stage in the life of the experiment.

\section{ROTATIONAL GRAZING v. SET STOCKING}

To obtain further data on herbage production under these two systems a trial with three ryegrass mixtures has been sown. The mixtures are perennial ryegrass plus clovers, short-rotation ryegrass plus clovers, and perennial plus short-rotation ryegrass plus clovers. These will be grazed during the winter with dry sheep, but in the spring ewes and lambs will be introduced, not to compare carrying capacities, but to obtain further information on the effect of the two systems on fat lamb production. 